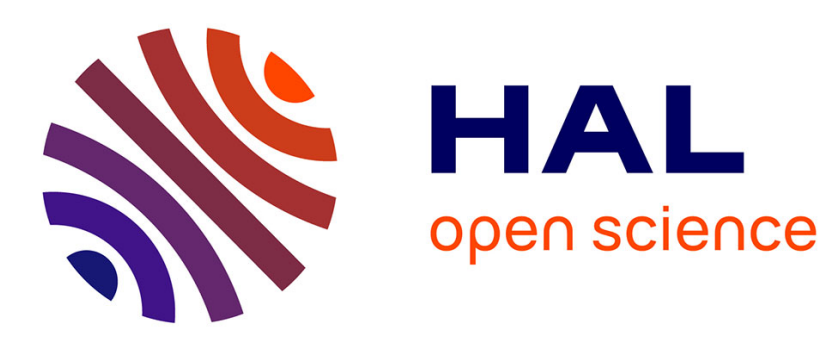

\title{
Solid-State Chemistry in France: Structures and Dynamics of a Scientific Community since World War II \\ Pierre Teissier
}

\section{To cite this version:}

Pierre Teissier. Solid-State Chemistry in France: Structures and Dynamics of a Scientific Community since World War II. Historical Studies in the Natural Sciences, 2010, 40 (2), pp.225-256. halshs00834995

\section{HAL Id: halshs-00834995 \\ https://shs.hal.science/halshs-00834995}

Submitted on 22 Jun 2013

HAL is a multi-disciplinary open access archive for the deposit and dissemination of scientific research documents, whether they are published or not. The documents may come from teaching and research institutions in France or abroad, or from public or private research centers.
L'archive ouverte pluridisciplinaire HAL, est destinée au dépôt et à la diffusion de documents scientifiques de niveau recherche, publiés ou non, émanant des établissements d'enseignement et de recherche français ou étrangers, des laboratoires publics ou privés. 


\title{
Solid-State Chemistry in France: Structures and Dynamics of a Scientific Community since World War II
}

\begin{abstract}
This paper tells the history of solid-state chemistry in France from 1945 to the present. There, the chemical study of solids was carried out by a national, academic community of solid-state chemists, which went through three successive organizational regimes. It was first framed by prewar traditions, taking the form of a feudal regime of Parisian research schools until the late 1950s. As the first post-World War II generation gained power and influence, research schools tended to drop their local specificity and the same disciplinary matrix spread across the country. This disciplinary regime was made possible through the centralized administration of the Centre national de la recherche scientifique (CNRS). Finally, a multiplication of practices and socializations blurred common standards in the 1980s, which shifted the community toward a cluster regime where numerous thematic groups loosely interacted under a broader umbrella influenced by materials science.

This case study investigates the institutional and epistemic structures and dynamics of a scientific community in a national context. The empirical analysis relies heavily on oral history, which affords special attention to the perceptions, discourses, and identities of the actors. The self-identification of chemists not only reflected their own beliefs but also constantly referred to their alter egos, the French solidstate physicists.
\end{abstract}

KEY WORDS: solid-state chemistry, solid-state physics, materials research, oral history, scientific community, French science policy, CNRS, industry, instrumentation

*Université Paris Ouest—Nanterre La Défense; personal address: 173 rue de Charenton, 75012 Paris, France; pierreteissier@yahoo.com.

The following abbreviations are used: ANVAR, Agence nationale de valorisation de la recherche; CEA, Commissariat à l'énergie atomique; CECM, Centre d'études de chimie métallurgique; CGP, Commissariat général du plan; CNRS, Centre national de la recherche scientifique; DGRST, Direction générale de la recherche scientifique et technique; IRSID, Institut de recherche de la sidérurgie.

Historical Studies in the Natural Sciences, Vol. 40, Number 2, pps. 225-258. ISSN I939-I8II, electronic ISSN 1939-I82X. (C) 2010 by the Regents of the University of California. All rights reserved. Please direct all requests for permission to photocopy or reproduce article content through the University of California Press's Rights and Permissions website, http://www.ucpressjournals.com/reprintinfo. asp. DOI: IO.I525/hsns.2010.40.2.225. 
While the history of solid-state physics has been investigated by scholars, there is no similar study of its chemical counterpart. ${ }^{1}$ Solid-state chemistry is either annexed by physics or simply ignored by modern historiography. ${ }^{2}$ Yet, if it can be considered a sub-field of materials research in the same way as solidstate physics, crystallography, or materials science and engineering, by no means can it be reduced to one of them or subsumed by all of them. ${ }^{3}$ Since the late I940s, solid-state chemistry has been a booming research field that has developed its own set of practices and beliefs and achieved a certain institutional autonomy. In other words, it has become a distinctive, vivid, but largely ignored scientific sub-culture in the age of materials.

This article is meant partly to fill the historiographic gap by telling the history of solid-state chemistry in France since World War II. The French case is remarkable because solid-state chemistry there was entrenched within national borders and academic boundaries, while its achievements were known far beyond. In France, the chemical study of solids was carried out by a national, academic community of solid-state chemists. The following narrative tells the life story of this community over sixty years. Rather than an essential, immutable body, a scientific community can be characterized by a set of parameters-four in this case. First, the members of a community define themselves as such; that is why actors' testimonies constitute the heart of this narrative. ${ }^{4}$ Members of a scientific community also share similar laboratory practices, especially related to objects of study,

I. Lillian Hoddeson, Ernest Braun, Jürgen Teichmann, and Spencer Weart, eds., Out of the Crystal Maze: Chapters from the History of Solid-State Physics (Oxford: Oxford University Press, 1992).

2. Solid-state science usually refers to physics only, as exemplified by Lillian Hoddeson, "Solid State Science," in Science in the Twentieth Century, ed. John Krige and Domique Pestre (Amsterdam: Harwood Academic Publishers, 1997): 585-98, on 585: "the 'new' scientific subfield which by the mid-I940s came to be known as 'solid state science,' or more commonly, 'solid state physics' (and more recently 'condensed matter physics')."

3. Although there is no history of materials research, it can be defined as a large umbrella overlapping the academy and industry and devoted to research and development of materials during the twentieth century. It includes materials science and engineering, which emerged in a specific context - that of the Cold War in the United States, as analyzed by Bernadette BensaudeVincent, "The Construction of a Discipline: Materials Science in the United States," Historical Studies in the Physical and Biological Sciences 31, no. 2 (200I): 223-48.

4. Since oral testimonies are omnipresent, an individual is explicitly named only when he/she is literally quoted (my own translation from French). As the testimonies tend to overestimate the role of great men, each time a great man is recalled, this includes the many people who remained in his shadow-researchers, technicians, and students—and contributed their works and words. Oral history is cross-checked with written sources such as textbooks, articles, conference speeches, obituaries, reports (CNRS, French Chemical Society), and personal documents (French Academy of Sciences, private collections). 
methods, and instruments, as well as a common space of socialization, bound together by institutions, conferences, and publications. These three parametersself-identification, similar practices, and common socialization—delimit the inside of a community, which interacts with outsiders - the fourth parameter. ${ }^{5}$

For six decades, from 1945 to the present, the French community of solid-state chemists encompassed three successive forms: a feudal regime of Parisian research schools until the late I950s; a nationwide, centralized disciplinary regime from the early I960s to the mid-I980s; and a dispersed cluster regime from the late 1980s onward. The body of the narrative will successively consider these three organizational regimes, and for each era, draw a detailed picture of the community.

This case study is important for at least three reasons. First, it provides an empirical account of the synchronic structures (picture of a regime) and diachronic dynamics (succession of eras) of a contemporary scientific community. It is noteworthy that even though each era cohered around an archetypal regime, the community was never homogeneous, as it was constantly impelled by competing local heterogeneities. Second, this paper pays special attention to certain features of the French academic culture (state patronage, mandarins, research schools, etc.) and follows their evolution in a lively community for six decades. This sheds light on the still-crucial importance of national borders in France in the second half of the twentieth century. Third, this study provides an account of solid-state chemistry that mirrors the development of physics at the same time in France. This comparison gives the opportunity to discuss, in a contemporary context, the building process by which a research field becomes (or does not become) an academic discipline depending on the converging (or diverging) institutionalizations of research and education. But first let us set the stage upon which the narrative of the solid-state chemists will unfold.

\section{THE FRENCH ACADEMIC SYSTEM IN CONSTRUCTION}

\section{AFTER WORLD WAR II}

Following the liberation of France in 1944, the first priority of the provisional government was the modernization of the country and the building of new facilities. In January 1946, Charles de Gaulle, head of the provisional government

5. In spite of a large debt to Thomas Kuhn, The Structure of Scientific Revolutions, 2nd ed. (Chicago: University of Chicago Press, 1970), this four-parameter definition avoids the circularity of Kuhn's argument (which equates disciplinary matrix with scientific community) and stresses the role of social spaces, human relationships, and outside references. 
(June 1944-January 1946), created the Commissariat général du plan (CGP) to survey national economic needs and plan for the next five years. ${ }^{6}$ No place was given to science in the first two CGP plans (1947-1953 and 1954-1957) and no national research coordination was established before $1958 .^{7}$ In short, in 1945, science policy was "an empty shell" in France (une coquille vide). ${ }^{8}$ Academia and industry were loosely connected, and public research was fragmented among universities, engineering schools, and several new, goal-oriented state agencies that depended on several ministries.?

However, there was a state agency that played a specific role in this institutional patchwork: the Centre national de la recherche scientifique (CNRS). The CNRS had been established in 1939 to coordinate public research and to influence private industries but was never given the political means to do so. ${ }^{10}$ With its wide scope of research (from the humanities to the natural and social sciences); its size (three thousand employees in 1950 , half of whom were scientific researchers); and its dynamism (the average employee was under thirty in 1950), the CNRS became the major research agency in France. ${ }^{11}$ Although supervised by the same Ministry of Education as the universities, the CNRS retained administrative autonomy. It was organized as a "republic of scholars" with an appointed CNRS executive branch (Direction générale) and a parliament (Comité national). The parliament was divided into thirty sections between 1945 and 1960. Each CNRS section, initially centered on disciplines taught at universities, had around twenty representatives in the Comité national,

6. This state agency, which was inspired and first led by Jean Monnet (I888-1979), played a central advising role until the I980s. See William I. Hitchcock, France Restored: Cold War Diplomacy and the Quest for Leadership in Europe, 1944-1954 (Chapel Hill: University of North Carolina Press, 1998), 29-40.

7. Antoine Prost, "Les origines de la politique de la recherche en France (I939-1958)," Cahiers pour l'histoire du CNRS I (I988): 4I-62.

8. François Jacq, "Aux sources de la politique de la science: Mythe ou réalités? (1945-1970)," La Revue pour l'histoire du CNRS 6 (2002); available online at http://histoire-cnrs.revues.org (last accessed Io Jan 20IO).

9. For the civil agencies established between 1942 and 1946 in the domains of medicine, colonial management, steel industry, petroleum industry, nuclear industry, telecommunications, space industry, and agriculture, see Ghislaine Bidault, Les mémoires de recherche: Etat des versements, 1977-1989 (Paris: CNRS, 1993). For military research under the Fourth Republic (1944-1958), see Maurice Vaïsse, ed., La Quatrième République face aux problèmes d'armement (Paris: ADDIM, 1998).

Io. The CNRS was unable to coordinate public research because it was under the responsibility of a single ministry and not the prime minister. Prost, "Les origines" (ref. 7), 6I.

II. This paragraph is based on Jean-François Picard, La République des savants: la recherche française et le CNRS (Paris: Flammarion, 1990). See also Denis Guthleben, Histoire du CNRS de I939 à nos jours: une ambition nationale pour la science (Paris: Armand Colin, 2009). 
with two-thirds elected and one-third appointed. Each CNRS employee, who was a de jure member of one section, voted every four years to elect two-thirds of his or her Comité national. The parliament managed the CNRS laboratories (laboratoires propres) and the CNRS multidisciplinary commissions. In addition, it allocated individual grants to university professors. While there was a clear administrative distinction between the CNRS and the universities, their respective employees overlapped in everyday life. As the CNRS had relatively few laboratories and many employees, while the universities had relatively few employees and many laboratories, most CNRS employees worked in university laboratories where they had no teaching duties.

World War II had induced a generational break within the universities, and within each laboratory there was a large social gap between the professor and everyone else. The professor was a paternalistic, threatening figure who was addressed as "Sir" (Monsieur) and respectfully remembered as "the Boss" (le Patron). He held the discretionary power to rule the research groups and to determine the agenda of the laboratory and course curricula. In spite of the rise of influential research centers in the provinces since the nineteenth century, the Sorbonne in Paris remained by far the most prestigious university in France. It received around seventy percent of the funding allocated by the CNRS to the universities. Paris was still the haven of cumul and of the seniority system. ${ }^{12}$ As most professors of the Sorbonne retained their positions during the war, they continued to form a caste of "mandarins" after the war. ${ }^{13}$ It is noteworthy that this oligarchic caste allowed universities to keep most of the power in the French academe in spite of a thinner population in comparison with the CNRS. Indeed, in the early I950s, there were only two hundred professors, eight hundred assistant professors, and around twenty-five thousand students in fifteen faculties of science. ${ }^{14}$

I2. The description of the situation before I930 was still pertinent around I950: "A penurious salary scale at lower ranks and an expectation of bourgeois living at the higher ranks perpetuated the practice of cumul, the holding of multiple positions by a single scientist, which could most easily be done in Paris. Furthermore, cumul and a de facto seniority system only rarely allowed a younger scientist's election to a chair over the head of an elder." Mary Jo Nye, Science in the Provinces: Scientific Communities and Provincial Leadership in France, I860-1930 (Berkeley: University of California Press, 1986), 6.

13. The word "mandarin" was popularized by Fritz K. Ringer, The Decline of the German Mandarins: The German Academic Community, 1890-1933 (Cambridge, MA: Harvard University Press, 1969). A "mandarin" will refer hereafter to a scholar who concurrently holds key academic posts, receives numerous scientific awards, and enjoys social prestige.

I4. For natural and physical sciences, there were significantly fewer professors and assistant professors than CNRS researchers (one thousand versus fourteen hundred). Figures for the universities: Pierre Bourdieu, Homo Academicus (Paris: Les Éditions de Minuit, 1984), 270; for the CNRS: Picard, La République (ref. II), 214. 
As this narrative begins, the French academic system is in a state of confusion (as it has no science policy), suffers under a shortage of money and manpower (especially in the universities), remains framed by traditional university sub-disciplines, and is controlled by a caste of prewar mandarins.

\section{THE FEUDAL REGIME OF PARISIAN RESEARCH SCHOOLS,} 1945-1960

In the late 1940s, in France, the solid state was a fragmented object of study. Even if matter might be conceived in terms of three states—gas, liquid, and solid-this conceptual division was not entrenched in institutions. Until the I950s, no scientific discipline or sub-discipline was devoted to a single state of matter; each state of matter was investigated by several disciplines. Solid compounds were studied by disciplines ranging from physics to metallurgy, from crystallography to chemistry, and involved industries of glass, ceramics, and metals. The objects of research and the curricula were not the same. Solid-state chemistry was no exception: chemists studying solid compounds, or solid-state chemists, conducted research on high-temperature chemistry and reactions of solids. Simultaneously, they mainly taught mineral chemistry and their university departments were labeled mineral chemistry (two-thirds of them), physical chemistry (a quarter), and chemical metallurgy. In short, their research fields were different from their educational affiliations. Coherence of the community was to be found elsewhere through research schools' corporate culture.

\section{Discrepancy between Education and Research}

From the first half of the twentieth century, chemistry had been divided into four main sub-disciplines: organic, mineral, biologic, and physical. ${ }^{15}$ This partition discriminated matter according to composition (except for physical chemistry) rather than state. Mineral chemistry, which was the usual sub-discipline of solidstate chemists, dealt with mineral compounds in solid, liquid, and gaseous forms. ${ }^{16}$

15. There were also chairs of applied, theoretical, and fuel chemistries at the Sorbonne according to Christophe Charle and Eva Telkès, Les professeurs de la Faculté des sciences de Paris: Dictionnaire biographique I90I-1939 (Paris: éditions du CNRS, 1989). Industrial chemistry was taught in engineering schools.

I6. In spite of a large overlap, mineral differs from inorganic: the latter is forged as the opposite of organic and includes any compound without carbon in it, whereas the former comes from mines, which stresses the importance of mining compounds, especially solids. 
Its teaching was structured according to chemical elements: for each element, students learned endless catalogues of properties of solid, liquid, and gaseous species made of it. The bible of French mineral chemists, le Pascal, was paradigmatic of this element-based conception. ${ }^{17}$ The periodic table was the keystone of this empirical, descriptive, and encyclopedic knowledge.

Some of those who taught mineral chemistry typically conducted their research in two directions. First, some worked on high-temperature chemistry. ${ }^{18}$ Under the leadership of Paul Lebeau and Félix Trombe, a multidisciplinary CNRS commission on high temperatures and refractories gathered several dozen chemists, physicists, and industry engineers around the development of furnaces and their use in chemistry. Refractories, or heat-resistant materials, were usually metallic alloys or ionic crystals. ${ }^{19}$ As the refractories were of strategic importance to the ceramics, nuclear, and space industries, the CNRS commission developed suitable refractory materials for the French Atomic Energy Commission (CEA) and private corporations such as the Steel Industry Research Institute (IRSID), Saint-Gobain, and Le Carbone-Lorraine. Zircon $(\mathrm{ZrO} 2)$ was the star compound of the 1950 because of its high melting point and low cost. Chemists synthesized binary and ternary crystals at high temperature and characterized their thermal properties. ${ }^{20}$ They substituted one chemical element for another in the reactants to get the highest melting point at the lowest cost. When they needed a more systematic approach, they drew phase diagrams of ternary compounds. ${ }^{21}$ (Fig. I) As this practice required the

17. Paul Pascal, ed., Traité de Chimie minérale, I2 vols. (Paris: Masson, I93I-I932); 2nd ed., 20 vols. (Paris: Masson, 1956-1964). Each chapter focused on an element or a period of elements. For each element, every form of all the chemical compounds (gaseous molecules, coordination complexes, and solids) was listed, and their characteristics empirically described.

18. In France, this tradition had been launched by Henry Moissan's works on the electric furnace in the late nineteenth century (for which he received half of his 1906 Nobel Prize in Chemistry). It thrived in the I920s with the support of the Foundation Edmond de Rothschild for the development of scientific research.

19. A crystal is a solid with a short- and long-range atomic order. A metallic alloy is a crystal made of metallic elements. An ionic crystal is composed of both metallic elements and electronegative ones (such as $\mathrm{O}, \mathrm{S}, \mathrm{F}$, etc.).

20. A binary compound is composed of two different chemical elements, a ternary of three elements, and so on. High-temperature synthesis consists of mixing crystalline powders inside a crucible, grinding, and then heating the furnace at temperatures higher than the melting point of the mixture (usually between $\mathrm{I}, 000$ and $2,000^{\circ} \mathrm{C}$ ). The melt is eventually allowed to cool until it crystallizes.

2I. A phase is a thermodynamically stable crystal with a given atomic structure and composition. A phase diagram is a mapping of the different phases of a given compound: in Figure I, each area represents the domain of thermodynamic stability of a phase, each line a phase transition, and each point the determination of a crystalline structure by $\mathrm{x}$-ray diffraction. 


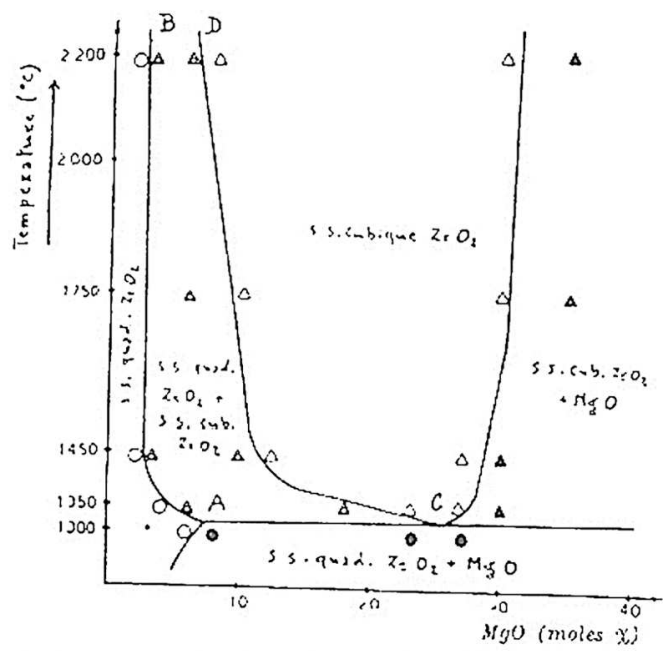

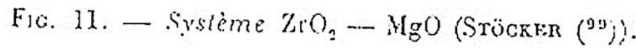
$\triangle$ cubique.
(5) quadratique.
A cubique + quadratique.
A cubique $+\mathrm{MgO}$.
- quadratique $+\mathrm{MgO}$.

FIG. 1 A Typical Phase Diagram of a Ternary Oxide (Zr-Mg-O). Source: le Pascal: Nouveau Traité de chimie minérale, vol. 9: Titane, zirconium, hafnium, thorium (Paris: Masson, 1963), 472. Courtesy of Éditions Dunod.

determination of crystalline structures by $\mathrm{x}$-ray diffraction, which was not affordable for a standard chemistry laboratory of the 1950s, chemists sometimes asked crystallography and physics laboratories to determine the structures for them. Through high-temperature chemistry, French solid-state chemists used their education in mineral chemistry to synthesize refractory crystals, collaborated in France with the materials industry and physicists, and interacted abroad with the U.S. community of high temperature technology. ${ }^{22}$

In parallel, some were also interested in the reactivity of solids. This field was pursued by a loose network of European chemists who gathered for the first time in Paris in 1948. Along with their Swedish and German counterparts, the French chemists were the leaders of the conference, which gathered about forty chemists and a few physicists. ${ }^{23}$ The phenomenon of non-stoichiometry

22. The French were active in symposia on high temperature technology, established in the mid-I95os in Asilomar (CA) by the Stanford Research Institute, which brought together approximately eight hundred researchers and industrialists.

23. The conference was organized by chemists, not by physicists, contrary to what Doris $\mathrm{T}$. Zallen wrote in "The Rockefeller Foundation and French Research," Cahiers pour l'histoire du CNRS 5 (1989): I-24, on 23. 
was used to explain the reactivity of ionic crystals and emphasized the role of lattice defects. ${ }^{24}$ Special attention was paid to two relationships: between geometrical criteria and solid-state reactivity; and between composition and physi$\mathrm{cal}$ and chemical properties of crystals. The influence of solid-state physics was obvious through the mention of lattice defects and the structure-property relationship. ${ }^{25}$ This 1948 conference marked the beginning of a series of international symposia on the reactivity of solids, held every four years since then.

Thus, solid-state chemists were simultaneously loyal to a traditional, element-based teaching (mineral chemistry) and studied a multitude of solids (refractory materials; organic, metallic and ionic crystals; and glasses and surfaces) in collaboration with ceramics, metallurgy, physics, and crystallography. Their education led them to deal with matter according to its composition while their research accustomed them to a given state of matter. These diverging logics were cohered by the research schools system.

\section{Chrétienté versus Chaudronnerie: A Case of Feudal War}

Once upon a time, mineral chemistry was a battlefield between two feuding familiesalmost scientific empires - called Chrétienté and Chaudronnerie. The former, directed by André Chrétien, tackled mineral compounds in aqueous and non-aqueous solutions by focusing on chemical rather than physical characterizations in the impregnable fortress of the Sorbonne. The latter, named after its charismatic leader, Georges Chaudron, investigated metallic alloys and oxides by crossing the methods of metallurgy and chemistry. This interdisciplinary research was labeled "metallurgical chemistry" and heralded by the laboratory of Vitry-sur-Seine, jewel of the CNRS. Beyond the opposition of topics—chemistry of solutions versus high-temperature chemistryeach side battled at a social level within committees and at conferences, each act designed to reduce the institutional and symbolic power of the foe. ${ }^{26}$

This picaresque legend with its ironical tone and mythical dimensions gives an idea of how the community of solid-state chemists was framed in the post-World

24. A non-stoichiometric compound is a solid with an elemental composition that cannot be represented by a ratio of natural numbers. For example: in $\left(\mathrm{ZrO}_{\mathrm{X}}\right)$, "x" can vary continuously.

25. For the importance of lattice defects in the semiconductor industry in the late I940s, see Michael Riordan and Lillian Hoddeson, Crystal Fire: The Birth of the Information Age (New York: W. W. Norton \& Company, 1997). The "structure-property relationship" means that there is a reciprocal correlation between the atomic structures and the physical properties of a crystal. It was one of the three pillars of solid-state physics since the r930s as described by Spencer Weart, "The Solid Community," in Out of the Crystal Maze (ref. I): 617-69.

26. This story is a written reconstruction by the author of similar oral versions told by some solid-state chemists who were PhD candidates just after World War II. 
War II decade. ${ }^{27}$ It was seemingly forged and told by the first postwar generation of students when they entered the milieu (circa 1945-1955) and met the prewar mandarins, André Chrétien and Georges Chaudron. ${ }^{28}$ This oral discourse emphasizes the centrality of "great men" in French culture (no great women here!) ${ }^{29}$ But above all, it clarifies the self-identification of solid-state chemists. The primary affiliation of each one was neither his or her education nor his or her research topics, but his or her research school organized around the emblematic figure of the mandarin. Here, the two rival research schools, Chrétienté and Chaudronnerie, crystallized the landscape around two opposing styles.

The Chrétienté was organized around the Sorbonne's Laboratory of Mineral Chemistry, where Chrétien was appointed professor in 1943. Here he developed chemistry of solutions, both in aqueous and non-aqueous solvents, and indiscriminately investigated precipitates, complexes, solutions, and solid-gas interactions. His personal leitmotiv was to work as a chemist, i.e., to favor synthesis and analysis rather than physical methods, original synthesis and chemical intuition rather than expensive devices. ${ }^{30}$ His laboratory was formally divided into three groups: solubility equilibriums, physico-chemical methods, and synthesis. Chrétien also favored the spread of his former pupils either to the chemical companies (Potasse et produits chimiques, Thann et Mulhouse, Pechiney, Saint-Gobain) or to the provincial universities (Pierre Laurent in Pau, Alfred Rohmer in Strasbourg, Alfred Deschanvres in Caen).

27. There is a pun in French since Chrétienté means Christendom (Chrétien was Catholic) while Chaudronnerie refers to the brotherhood of boiler manufacturing (quite appropriate for metallurgists).

28. Prewar mandarins and prewar generation refer to the generation of Chaudron and Chrétien, who were born in the late nineteenth century and who were in charge in the mid-r940s. The first postwar generation is formed by those who were directly supervised by the prewar generation during their $\mathrm{PhD}$ (ca. 1945-1955). These categories are relevant because of the generation break induced by World War II.

29. About the specific celebration of "great men" in France, see Pnina Abir-Am and Clark A. Elliott, eds., Commemorative Practices in Science: Historical Perspectives on the Politics of Collective Memory, Osiris I4 (1999), 30.

30. In 194I, in a proposal for an application, Chrétien wrote: "Physical methods must be considered as the auxiliaries of chemical research. . . It is obvious that one does not work enough as a chemist any more." André Chrétien, Notice sur les titres et travaux scientifiques (Archives de l'Académie des sciences, 194I). In 1948, in a conference, he said: "I think that the great methods of modern physics (infrared, Raman, electrons, and even x-ray) must be used secondly (dans un deuxieme temps) to put to the test ... the analysis and the synthesis are still, like in Lavoisier's era, the true methods of chemistry." André Chrétien, "Recherches récentes de Chimie Minérale," Bulletin de la Société industrielle de Mulhouse 2 (1949): 3I-7. 
The Chaudronnerie was built around the CNRS Research Center of Metallurgical Chemistry (CECM) at Vitry-sur-Seine in the Parisian suburbs, where Chaudron took advantage of the CNRS's expansion while remaining out of reach of the Sorbonne. ${ }^{31}$ Chaudron, who had been educated as a chemist and taught mineral and industrial chemistry throughout his career, devoted his research to metallic alloys and oxide crystals. He organized the CECM around thematic teams (services) — x-ray diffraction, ionic crystals, metallography and metallic alloys, electrochemistry and surface treatments, metals of high purity, etc.- -and a workshop (atelier) to repair and set instruments. He placed his most charismatic former pupils-René Faivre, Jacques Bénard, André Michel, Paul Lacombe, and Robert Collongues - at the head of research teams. ${ }^{32} \mathrm{Si}$ multaneously, he stressed the importance of industrial applications and knowledge transfer from one field to another, especially between metallurgy and chemistry. ${ }^{33}$ Although Vitry-sur-Seine was located an hour outside of Paris, the CNRS had enough fame and research grants (fifteen in 1953) to attract numerous $\mathrm{PhD}$ candidates from universities and engineering schools, and also from abroad. Under the strong authority of the master, the young people formed a cohesive group in a lighthearted atmosphere. (Fig. 2) In the I950s, the CECM was considered the jewel of the CNRS and the most famous laboratory of solid-state chemistry. It received more public funding than the prestigious center of Louis Néel (1904-2000) in Grenoble, the Laboratory of Electrostatics and Physics of Metal. ${ }^{34}$ It actively contributed to the study of reactions of solids (Chaudron and Bénard organized the 1948 conference in Paris) and hightemperature chemistry (Chaudron and Collongues became dominant in the CNRS commission in the late 1950s).

Thus, Chrétienté and Chaudronnerie had two epistemic divergences: a splitting of scientific objects between wet and dry chemistries, and a differentiation of

3I. For a detailed history by a former CECM researcher, see Michel Cornet, "Histoire du centre d'études de chimie métallurgique," Cahiers pour l'histoire du CNRS 5 (1989).

32. Centre d'études de chimie métallurgique (Laboratoire de Vitry du CNRS) (Paris: J. \& R. Sennac, 1954).

33. On all CECM documents, Chaudron printed this quotation by the American astronomer, Walter Adams (1876-I956): "In a research center, every single progress in a given domain must immediately be applied to the several fields of the center." Hélène Mondange, interview by author, I3 Dec 2004, Paris.

34. However, Néel's laboratory had more industrial funding, as was clearly stressed by Dominique Pestre, "Louis Néel, le magnétisme et Grenoble. Récit de la création d'un empire physicien dans la province française 1940-1965," Cahiers pour l'histoire du CNRS 8 (I990): I-I88. 


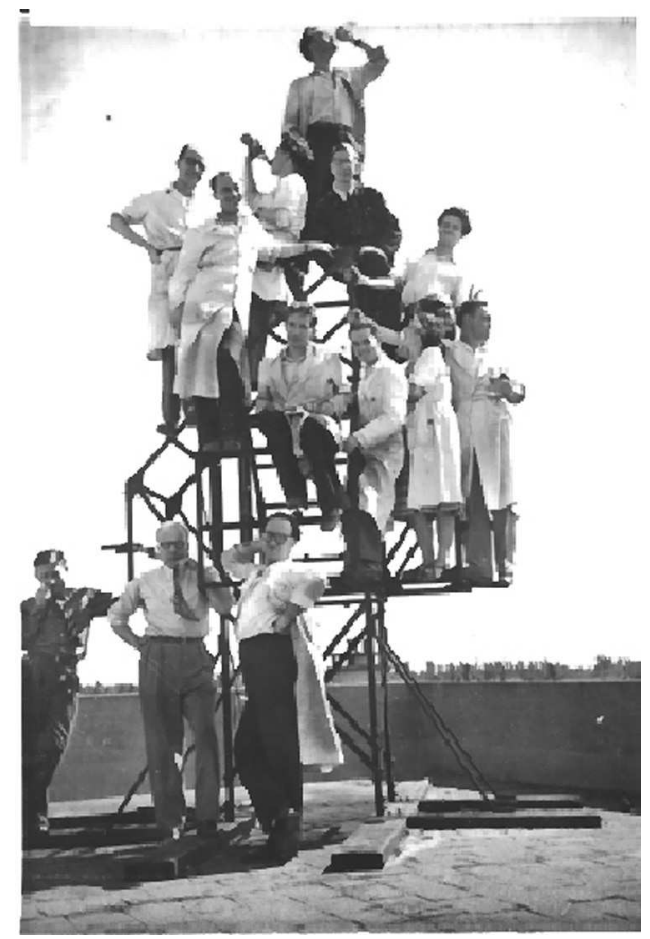

FIG. 2 The Beginnings of the CECM: A Light-Hearted, Young Research Group, Jul 1949. Source: Hélène Mondange personal papers.

methods between chemical and multidisciplinary perspectives. ${ }^{35}$ The urge to protect chemistry advocated by Chrétien was more widespread among French chemists than the knowledge-transfer applied by Chaudron. These differences were enhanced by a long-standing rivalry between the former masters of Chrétien and Chaudron and by a current antagonism between the venerable university and the young CNRS. ${ }^{36}$ As a result, each side sought to reduce the influence of the rival

35. The terminology dry and wet chemistry is mentioned by American electrochemists to distinguish the solid state from liquid solutions. Forrest A. Trumbore and Dennis R. Turner, The Electrochemical Society. 1902-2002: A Centennial History (Pennington: The Electrochemical Society, 2002), 2.

36. The respective masters of Chaudron (Henry Le Chatelier) and Chrétien (Georges Urbain) were already in competition: Le Chatelier, Catholic and pragmatic, promoted industrial science in the I920s at the Sorbonne while Urbain, an atheist and rationalist, fought to keep the university free from applied sciences. See Michel Letté, Henry Le Chatelier (I850-1936) ou la science appliquée à l'industrie (Rennes: Presses Universitaires de Rennes, 2004); and José Manuel Claro Gomès, "Georges Urbain (1872-1938): Chimie et philosophie" (PhD dissertation, Université Paris Io Nanterre, 2003). 
in the committees and conferences. Each school struggled to secure institutional positions for its kin, to get funding through industrial collaborations, and to convince the community of the excellence of its methods and results.

\section{The Parisian Regime of Empirical Research Schools}

In spite of their differences, Chrétienté and Chaudronnerie each displayed several common features of a research school. ${ }^{37}$ At the heart of the research school, the laboratory was structured by a division of labor based on age, gender, and education. Strict everyday rules were applied to stress these differences. In spite of informal behaviors (since the master was not present, see Fig. 2), it was compulsory to respect the dress code to enter the laboratory: suit and tie under a white laboratory coat for male researchers; a dress or skirt (and no trousers allowed) for women researchers and technicians. The way of life was very familial. ${ }^{38}$ However bad their conditions might have been, young people's loyalty and dependence were such that they either did not want to leave their research school (because of their familial ties), or could not leave their research school (because their mandarins would refuse to help them transfer to a rival school). ${ }^{39}$ This patriarchal system, which favored a concentration of power and a sedentary lifestyle, was still remarkably similar in the 1950 in France to the system of the previous century in the rest of Europe.

Although paradigmatic of the era, the harsh competition between Chaudronnerie and Chrétienté included only half of French solid-state chemists. At least four other research schools were involved; each was headed by a charismatic leader-Lebeau, Trombe, Louis Hackspill, and Paul Mondain-Monval—whose headquarter laboratory was in the Parisian area. These six research schools, whose genealogy and generation affiliations are shown in Figure 3, had distributed the

37. See the seminal definition by Gerald L. Geison, "Scientific Change, Emerging Specialties, and Research Schools," History of Science (1981): 20-40; and the special issue edited by Gerald L. Geison and Frederic L. Holmes, Research Schools: Historical Reappraisals, Osiris 8 (1993).

38. The central position in a research school of a domineering father figure has already been emphasized, for example, by Jack Morrell, "The Chemist Breeders: The Research Schools of Liebig and Thomas Thomson," Ambix I9 (1972): I-46. But familial features like heredity, brotherhood, and jealousy, while rarely considered by historians, were crucial for the actors, who explicitly compared research schools to blood-related families.

39. The case of Hélène Mondange, although extreme, is significant: her PhD at the CECM took ten years (1948-1958), in comparison with an average duration of four to five years at the time, because Chaudron let her wait for a subject (for more than one year) and used her for several teaching and administrative activities. However, she still has vivid and happy memories of Chaudron. Mondange, interview, I3 Dec 2004 (ref. 33). 


\begin{tabular}{|c|c|c|c|c|c|c|}
\hline & \multicolumn{6}{|c|}{ Research Schools } \\
\hline Ancestors & \multicolumn{2}{|c|}{$\begin{array}{c}\text { Henry } \\
\text { Le Chatelier } \\
(1850-1936)\end{array}$} & \multicolumn{2}{|c|}{$\begin{array}{c}\text { Georges } \\
\text { Urbain } \\
(1872-1938)\end{array}$} & \multicolumn{2}{|c|}{$\begin{array}{c}\text { Henry } \\
\text { Moissan } \\
(1852-1907)\end{array}$} \\
\hline $\begin{array}{l}\text { Prewar } \\
\text { generation } \\
\text { (Ph.D. before } \\
\text { 1945) }\end{array}$ & $\begin{array}{l}\text { Paul } \\
\text { Mondain- } \\
\text { Monval }\end{array}$ & \begin{tabular}{|l|} 
Georges \\
Chaudron \\
(1891-1977) \\
Hubert \\
Forestier \\
André \\
Michel \\
Jacques \\
Bénard \\
(1912-1987) \\
René Faivre \\
Paul \\
Lacombe \\
\end{tabular} & $\begin{array}{l}\text { André } \\
\text { Chrétien } \\
\\
\\
\text { Pierre } \\
\text { Laurent } \\
\text { Alfred } \\
\text { Rohmer }\end{array}$ & $\begin{array}{l}\text { Félix } \\
\text { Trombe } \\
\text { (1906-1985) }\end{array}$ & $\begin{array}{l}\text { Paul Lebeau } \\
\text { (1868-1959) }\end{array}$ & $\begin{array}{l}\text { Louis } \\
\text { Hackspill } \\
(1880-1963)\end{array}$ \\
\hline $\begin{array}{l}\text { First postwar } \\
\text { generation } \\
\text { (Ph.D. } \\
\text { 1945-1955) }\end{array}$ & René Pâris & \begin{tabular}{|l|} 
Robert \\
Collongues \\
$(1924-1998)$ \\
Hélène \\
Mondange \\
(b. 1925) \\
Gérard \\
Montel \\
\end{tabular} & \begin{tabular}{|l|} 
Paul \\
Hagenmuller \\
(b. 1921) \\
Jacques \\
Prigent \\
Alfred \\
Deschanvres
\end{tabular} & & \begin{tabular}{|l} 
Jean \\
Flahaut \\
(b. 1921) \\
André \\
Boullé
\end{tabular} & $\begin{array}{l}\text { Albert } \\
\text { Hérold (b. } \\
\text { 1921) }\end{array}$ \\
\hline $\begin{array}{l}\text { Second postwar } \\
\text { generation } \\
\text { (Ph.D. } \\
\text { 1955-1970) }\end{array}$ & & $\begin{array}{l}\text { Jean-Claude } \\
\text { Bernier } \\
\text { Andrée } \\
\text { Kahn-Harari } \\
\\
\text { Jacques } \\
\text { Livage }\end{array}$ & \begin{tabular}{|l} 
Jean Rouxel \\
(1935-1998) \\
Michel \\
Pouchard \\
Jacques \\
Lucas \\
Michel \\
Tournoux \\
Jean Galy \\
Roger \\
Naslain \\
Michel \\
Raveau
\end{tabular} & Paul Caro & & \\
\hline
\end{tabular}

FIG. 3 Genealogy and Generation Affiliations of French Solid-State Chemists. Source: Table constructed by author.

solid state according to an element-based division of the periodic table: oxides and metals went to Chaudron, chlorides to Chrétien, sulfides to Lebeau, alkalines to Hackspill, rare earths to Trombe, and glasses and metals to MondainMonval. Such a share-out secured a private domain for each school and reduced the empirical (but not the economic and symbolic) competition among them. Each school also conducted specific research: high-temperature chemistry for Lebeau, Trombe, and Chaudron; reactivity of solids for Chaudron and Trombe; wet chemistry for Chrétien, Hackspill, and Mondain-Monval; and gas chemistry for Lebeau and Hackspill. 
In spite of these specializations, all shared a trust in experimentation and a distrust of theoretical models, preferring empirical precision to theoretical simplification. ${ }^{40}$ This orientation toward experimental realism rather than mathematical tractability was sustained by two factors: the disciplinary affiliation to mineral chemistry (more dedicated to the cataloguing of facts than the establishment of laws) instead of physical chemistry; and the close connection to the refractory industry (through high-temperature research) instead of the semiconductor industry. ${ }^{41}$

Until the late I950s, the community of solid-state chemists was framed by a feudal regime of research schools concentrated in Paris. In a space where mobility was the exception and hierarchy the rule, the mandarins, who were able to travel and retained power within the system, were omnipotent and gave coherence to the whole. The community was not defined by standardized practices (as shown by the wide range of objects of study), but by loyalties to a research school and acknowledgments of rivals. The antagonism between research schools was embedded in local socializations and a dividing up of the periodic table. Since its boundaries were not institutionalized, the community remained unclear for outsiders, but locally, each research school could interact with the outside: physics, industry, and abroad.

\section{CNRS'S DISCIPLINARY REGIME, 1960-1985}

In the next era, the Parisian feudal university system was destabilized by an unprecedented growth of the academic system and the rise of the CNRS, which became powerful enough to challenge the university system. The first postwar generation encouraged bottom-up educational aspirations and oriented top-down decisions from the centralized CNRS to gather the community of solid-state chemists around a standardized disciplinary matrix. The standardization, which favored physical characterizations at the expense of chemical practices, was perceived as a physical

40. A significant anecdote was told about Chaudron: he quarreled with Nevill Mott (I9051996) in a conference and accused the theoretician from Bristol (who would earn the Nobel Prize in Physics in 1977) of having misinterpreted an experimental result published by one of Chaudron's students to promote a theoretical model.

4I. The refractory industry was more empirical than the semiconductor industry, where the theory of bands was inescapable. When physicists developed semiconductors in France around I950, they did not turn toward their chemist colleagues, but rather consulted American physicists or German chemists. See Maurice Bernard, "Le CNET et les semi-conducteurs, du début des années 1950 au milieu des années 1960," in Histoire, recherche, télécommunication: Des recherches au CNET, 1940-1965, ed. Michel Atten (Paris: CNET, Réseaux, 1996), I47-60. 


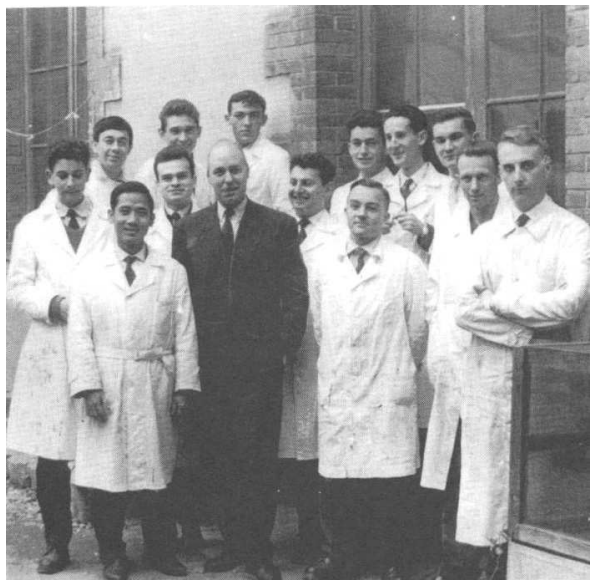

FIG. 4 Paul Hagenmuller and His Students, Laboratory of Mineral Chemistry A, University of Rennes, late 1950s. Source: Jacques Lucas personal papers.

turn and labeled with the stamp of modernity. With the convergence of research and education, solid-state chemistry was becoming a conspicuous academic discipline, and the community experienced a disciplinary regime.

\section{The Reformation of Universities in the Provinces}

In 1956, the Congress of Caen made clear the shortage of scientists in France. ${ }^{42}$ From the late I950s onward, new universities were built across the country and new laboratories settled in the provinces. Between 1950 and 1968 , the number of science students multiplied six-fold (from twenty-five thousand to one hundred fifty thousand) and teaching staff ten-fold (from one thousand to ten thousand) ${ }^{43}$ At the same time, the number of solid-state chemists increased five-fold, from about one hundred researchers to five hundred. The count of research centers climbed from a dozen to forty. This overall rise was not due to disciplinary migrations but to the coming of new generations, which brought fresh blood into the academic system.

Because prewar mandarins held the tenured positions in Paris, the first postwar generation, then in their thirties, moved to less prestigious provinces where they were simultaneously appointed university professor and laboratory director. Figure 4 is emblematic of the new arrangement: in 1956, at the age of 
thirty-five, Paul Hagenmuller, an offspring of the Chrétienté in disgrace, became professor of mineral chemistry at the University of Rennes, in Brittany. He and his research team of a dozen $\mathrm{PhD}$ candidates became so well known that the University of Bordeaux made an exceptional offer to them and they moved there in 1960-196I. This embodied a significant change: because of the growth and spread of resources across the country, it became possible around I960 to succeed outside Paris and without the support of the former master (Hagenmuller had quarreled with Chrétien, for example). Prewar mandarins, who kept symbolic powers in Paris, left most lecture halls and laboratory benches to the first postwar generation. Young and charismatic professors like Robert Collongues or René Pâris could renew element-based, descriptive courses of mineral chemistry in light of their own solid-state research. First postwar-generation professors educated the second postwar generation (circa 1955-1970) with stimulating courses incorporating crystallographic analyses, industrial case studies, and brief mentions of the theory of bands (for model compounds). ${ }^{44}$ The teaching shifted to the crossroads of mineral and physical chemistry, and solidstate research topics. ${ }^{45}$

\section{A National Reorganization Centralized by the CNRS}

After they took local power in provincial universities, the first postwar generation turned their sights toward the CNRS as its size, funding, and prestige increased. ${ }^{46}$ The centralism of the CNRS allowed it to exert a deep influence on the universities, which then became subordinated to it. ${ }^{47}$ CNRS's Jacobin republic substituted for the feudal regime of the universities. The best place to control national research became the CNRS parliament, where young ambitious men wanted to

44. The second postwar generation is defined by the same principle as the first one: they were directly supervised by the first postwar generation during their $\mathrm{PhD}$, circa $1955-1970$ studies. As there is no generational break similar to World War II then, the temporal limits are less precise.

45. These courses referred to textbooks of mineral chemistry such as le Pascal (see ref. 17) and of physical chemistry such as Linus Pauling, General Chemistry: An Introduction to Descriptive Chemistry and Modern Chemical Theory (San Francisco: W. H. Freeman and Company, 1947), translated in French by Pâris in 195I.

46. From I950 to 1970, the CNRS budget increased twenty-fold (at constant francs) and its size increased five-fold, from three thousand to fifteen thousand employees. Picard, La République (ref. II).

47. Burton R. Clark, Places of Inquiry: Research and Advanced Education in Modern Universities (Berkeley: University of California Press, 1995): chap. 3, "France: Subordination of the University." 
sit. As most solid-state chemists were affiliated with mineral chemistry, first postwar-generation professors like Collongues, Hagenmuller, and Jean Flahaut joined the Comité national of mineral chemistry. ${ }^{48}$ In the 1960s, solid-state chemists were the de facto leaders of the Mineral Chemistry section of CNRS. ${ }^{49}$

This was precisely the time when the CNRS's influence over the academy rose. Until the mid-196os, the Comité national was only in charge of CNRS laboratories (three were linked to solid-state chemistry) and CNRS employees' careers (around a hundred solid-state chemists)..$^{50}$ But, in 1966, the CNRS executive branch created a new label: the association of university laboratories to the CNRS (laboratoires associés). Since the association allowed university laboratories to gain prestige, funding, and positions, the logical strategy of the laboratories became to please the Comité national. As the association required a critical mass, small research teams from distinctive research schools merged: the most significant was the fusion of three teams in Nancy in 1966-metallurgy (Faivre), industrial chemistry (Albert Hérold), and mineral chemistry (Jacques Aubry) — to found the Laboratory of Metallurgy and Solid-State Chemistry. ${ }^{51}$ The number of affiliated laboratories of solid-state chemistry grew from five in 1967 to twenty-five ten years later; most of them were in the provinces. ${ }^{52}$ The decade 1966-1975 was thus marked by the progressive bonding of most solid-state chemists to the CNRS through the association of their laboratories. This massive association accustomed solid-state chemists to a nationwide research community driven by the Comité national.

48. University professors were eligible for the Comité national, whereas CNRS employees were not eligible for university committees. Good politicians like Collongues and Hagenmuller became influential enough to work around the rules and be elected or appointed time after time.

49. Between 1959 and 1975, the successive presidents of the section of Mineral Chemistry were all solid-state chemists: Hackspill (1959-196I), Chaudron (I96I-1967), Étienne Bonnier (1967-1970), Michel (1971-I975).

50. There was the CECM (sixty-seven researchers and forty-four technicians in 1966), the Laboratory of Rare Earths (fifteen and eighteen) and the Laboratory of Solar Energy (eight and forty). Michelle Charpentier-Morize, "La contribution des 'Laboratoires Propres' du CNRS à la recherche chimique en France de 1939 à 1973," Cahiers pour l'histoire du CNRS 4 (1989): 79-II2.

5I. In 1958, Aubry was offered a professorship by Néel in Grenoble but refused because he did not want to betray Nancy, according to Pestre, "Louis Néel" (ref. 34), I35.

52. Four of the five solid-state chemistry laboratories associated in 1966 and 1967 were in the provinces: Nancy (Laboratory of Metallurgy and Solid-State Chemistry); Bordeaux (Laboratory of Mineral and Structural Chemistry, under Hagenmuller); Grenoble (Laboratory of Thermodynamics and Metallurgical Physico-Chemistry, under Bonnier); and Toulouse (Laboratory of Chemistry of Solids and High Temperatures, under Gérard Montel). The fifth was in the Mines of Paris where André Boullé and Lacombe gathered to found the Laboratory of Metallurgical and Chemical Research. Rapport d'activité du CNRS (Paris: 1966, 1967). 
The first consequence was that boundaries between research schools faded while the merging of research teams from different research schools (to reach a critical mass) multiplied. This was enhanced by the emergence of new networking capabilities with the popularization of conferences. Until the late I950s, only mandarins traveled and gave lectures, while young researchers stayed at the bench. In 1962, when the French Chemical Society decided to organize thematic lecture sessions (in Paris), more young solid-state chemists came from the provinces to attend because there was a specific session on ionic crystals. Two international CNRS conferences were organized soon afterward: the first by Hagenmuller on oxide crystals in Bordeaux (1964), the second by Chaudron on refractory materials in Paris (1965). In 1966, a solid-state physicist, Jacques-Paul Suchet (born in 1923) from the CNRS campus of MeudonBellevue, launched an annual seminar of solid-state chemistry to gather chemists and physicists in Paris. The seminar was so popular that it continued to be held annually for ten years (1966-1975). The Comité national and the CGP plan enthusiastically advertised this dynamism of solid-state research. ${ }^{53}$

The second consequence of the decade 1966-1975 was a disciplinary switch from mineral chemistry to solid-state chemistry. During the previous era (19451960), mineral chemistry was the referent discipline of prewar mandarins, and consequently, through the research schools' framework, of the whole community. When the prewar generation retired in the 1960 , mineral chemistry left with them, while new solid-state-based courses were introduced. It was precisely the decade when solid-state research was booming and solid-state chemists were organized by the CNRS as a nationwide research community. A number of first postwar-generation professors catalyzed this bottom-up educational renaissance with top-down institutional centralization, creating a convergence toward a new sub-discipline of chemistry: solid-state chemistry became a common reference for research and education. This superimposition was made possible through a standardization of practices and the forging of a second collective legend.

\section{The Standardization of Practices and the Second Legend}

The period between 1960 and 1975 was not characterized by original practices but by the standardization of older ones. Because of their interesting physical

53. Solid-state chemistry was first labeled a sub-discipline of chemistry in the 1967 Rapport d'activité de la section de chimie minérale and described as one of the most dynamic fields of chemistry in the same report in 1970. It was also mentioned as one of the scientific priorities of the fifth CGP plan (1966-1970) for which Bénard wrote the section devoted to chemistry. 
properties, ionic crystals became the main object of study, and high-temperature reactions the easiest way to synthesize them. The laboratories studying amorphous and organic solids as well as liquid precipitates became heterodox and were hindered by the Comité national. ${ }^{54}$ As the fourth CGP plan (19621965) increased public funding of science, $x$-ray diffraction devices became affordable for a standard chemistry laboratory and spread among the community. As x-ray diffraction gave a precise determination of crystalline structures, the studies in bulk became more valued than those in surface. ${ }^{55}$ The specialty of the French community became crystallo-chemistry (cristallo-chimie), an empirical know-how in synthesis at the intersection of chemistry and crystallography. ${ }^{56}$ This allowed the second postwar generation to produce a multitude of new binary, ternary, and quaternary ionic crystals for which they became famous abroad. ${ }^{57}$ In addition, interest in physical properties and the structureproperty relationship gradually increased..$^{58}$ The interest in thermal properties, which had been at the heart of the previous era, declined compared with electric, magnetic, and optic ones.

This physical turn normalized collaborations with physics in the 1960s. French solid-state physicists asked chemists' help because they needed single crystals instead of powder crystals for a more precise study of the structure-property

54. The laboratory of Pâris in Lyon, which synthesized fine-grain mixed-oxides by the "precursor method," could only find support in the industry (Rhône-Poulenc and Pechiney) and with physicists like Néel. Hérold's laboratory in Nancy, which studied the insertion compounds of graphite, received only support from the Research Group of Carbons, directed by Adolphe Pacault (I9I8-2008), an heir of Paul Pascal (I880-I968).

55. The bulk/surface split induced the migration of reactivity of solids beyond the scope of solid-state chemistry, at least in France. In 1984, when the Ioth Symposium on the Reactivity of Solids was again held in France (after Paris in 1948), it was organized by Pierre Barret's (192I-2004) Laboratory of Physical Chemistry in Dijon. No French solid-state chemists attended.

56. To be a good crystallo-chemist meant to be creative in the synthesis of new crystalline structures. This expertise relied on extensive drawings of phase diagrams, a willingness to handle dirty matter, and an intuitive understanding of the periodic table. It indicated the continuation of the experimental culture of the previous era.

57. A paradigmatic case is the synthesis of new phases of sulfides of molybdenum $\left(\mathrm{PbMo}_{6} \mathrm{~S}_{8}\right)$ by the research team of Jacques Prigent in Rennes in 1971. It was hardly noticed until 1972 when Bernd Matthias (1918-1980) revealed the superconducting properties of these compounds that became known as "Chevrel's phases" (named after one of Prigent's PhD students). Jean Matricon and Georges Waysand, La guerre du froid: une histoire de la supraconductivité (Paris: Seuil, 1994), $307-08$.

58. This is confirmed by a publication survey of Collongues's group: I00\% of articles were published in chemistry journals in $1950 ; 40 \%$ in chemistry and $40 \%$ in physics in $1975 ; 25 \%$ in chemistry and $60 \%$ in physics in 2000 . 
relationship. ${ }^{59}$ Until the I960s, chemists usually worked on powder crystals, but from then on, they grew single crystals, a process known as "cristallogenesis," for which they became worldwide experts by refining their knowledge in high temperatures. The synthetic expertise of chemists was an asset to physicists, and was thus at the heart of collaborations between the two.

The investigation of crystals with diverse properties also normalized collaborations between scholars and industrials. The turn toward industry was labeled the "property-application relationship." ${ }^{60}$ In the 1960s, Rhône-Poulenc funded numerous $\mathrm{PhD}$ grants in academic laboratories because they needed rare earth crystals to produce color TV screen pigments. In the I970s, chemists focused on beta-alumina and other superionic conductors with the hope of producing solid-state batteries and fuel cells. ${ }^{61}$ National energy utilities (Électricité de France), industrial gases supplier (Air Liquide), and automobile industry (Peugeot) largely funded solid-state chemists for these applications.

The standardization of practices and the normalization of relations with physics and industry took place while a new collective discourse was forged:

\begin{abstract}
After World War II, there were two foe "grandfathers"-Chaudron and Chrétienwho fathered two pioneers-Collongues and Hagenmuller — who in their turn had a large family of scientific heirs. Even if they were hindered by the prejudices of their time and by their endless rivalry, Collongues and Hagenmuller were visionary enough to turn chemistry toward physics and to make possible a significant breakthrough from an old-fashioned, descriptive, mineral chemistry to a modern, methodological, eventually predictive, solid-state chemistry. Solid-state chemistry became the study of ionic crystals through the double relationship of structure-property and propertyapplication. The French community became a worldwide leader in the field. ${ }^{62}$
\end{abstract}

59. Without special conditions, a mixture of powders crystallizes as a powder crystal, which is made of a multitude of micrometric grains bound together but randomly oriented. This random orientation avoids the characterization of anisotropic properties at the macroscopic level. On the contrary, with a single crystal made of a unique crystalline grain of macroscopic size (typically one centimeter), anisotropic properties can be observed.

6o. Much like the structure-property relationship, the property-application relationship meant that chemists had a special interest in properties that could lead to applications, or at least, to induce industrial collaborations.

6r. Beta-alumina ( $\left(\mathrm{II} \mathrm{Al}_{2} \mathrm{O}_{3}, \mathrm{x} \mathrm{Na}_{2} \mathrm{O}\right)$ with $\mathrm{x}$ over the whole range [I.o-I.6]) was investigated for its thermal properties by Collongues's laboratory in the I950s but was not popular until 1967 when Ford researchers revealed its superionic conductivity, i.e., the ability for an ionic crystal to display an electrical conductivity of the same order of magnitude as a good liquid electrolyte.

62. This second story is a written reconstruction by the author of similar versions told by second postwar-generation chemists. The fact that the second postwar generation presents a common discourse justifies the relevance of this category. As for the first postwar generation, they 
This second legend was shaped by the second postwar generation when they entered the milieu from the mid-I950s onward, encountered aging prewar mandarins, and were disciplined by first postwar-generation professors. Though it retained the emphasis on great men, this legend conveyed two new values. First, the great men ceased to be warlords (dynastic rivalries were no longer considered agents of cohesion) and rather became agents of modernity, leading from empirical to predictive chemistry. Second, modernization came from the outside: from physics with the "physicalization of chemistry" and from industry with the role of application. ${ }^{63}$ The public association of modernity and physics was typical of the CNRS's ideology; the novelty, however, could be found in the positive role given to industrial applications: in fact, this public discourse was happening contemporaneously with the establishment of an applied science policy in France from 1958 onwards. ${ }^{64}$

This new legend gave a simple, plausible, and appealing interpretation of a more complex process: it turned the standardization of practices and normalization of outside relations (mostly accomplished in Chaudronnerie) into the rise of modernity; it distorted the memory of the previous era (1945-1960) by stressing only the old-style chemistry (done in Chrétienté); and it fostered the unity of solid-state chemistry around ionic crystals and coalesced the community around the identity of the solidiste. ${ }^{65}$ In this respect, the linguistic switch from mineral to solid-state was successful since it replaced a craft word (mining) with an epistemic category of physics, queen of sciences. The second legend thus paved the way for the institutionalization of solid-state chemistry: the discipline was first imagined and later institutionalized. ${ }^{66}$

had both a common discourse (the first legend) and similar trajectories (in charge of the growth of universities from the 1950s onward).

63. The physicalization occurred later for solids than for molecules. For molecules, it took place in the first half of the century according to Carsten Reinhardt, Shifting and Rearranging: Physical Methods and the Transformation of Modern Chemistry (Sagamore Beach, MA: Science History Publications, 2006).

64. Public agencies were established to favor the collaboration between academe and industry: General Delegation to the Scientific and Technical Research (DGRST) in 1958, and National Agency for the Valorization of Research (ANVAR) in 1967. See Antoine Prost, "Les réformes du CNRS, 1959-1966," Cahiers pour l'histoire du CNRS 9 (1990): 7-38.

65. The term "solidiste" was a neologism coined by French solid-state chemists in the I96os. To be a solidiste meant to acknowledge solid-state chemistry as the primary professional affiliation for research and education, which was new.

66. The creation of a discipline, which is the imagination of an epistemic category that is later embedded in institutions, is thus similar to the building of a nation-state as described by Benedict Anderson, Imagined Communities: Reflections on the Origins and Spread of Nationalism (London: Verson, 1983). 


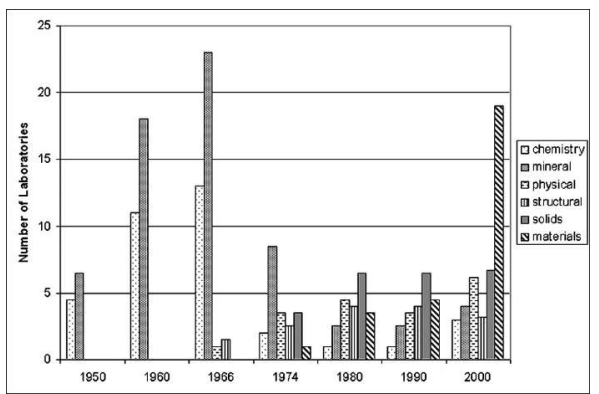

FIG. 5 Semantic Evolution in the Name of the Academic Laboratories of Solid-State Chemistry in France, 1950-2000. Source: Graph by author.

By the early 1970s, half of the laboratories changed their name and replaced the term "mineral chemistry" with physical, structural, solid-state, or materials chemistry. (Fig. 5) In 1974, Hagenmuller's laboratory in Bordeaux became a CNRS center as the Laboratory of Solid-State Chemistry. The following year, when the CNRS executive branch modified the sections for the third time (after 1960 and 1966), the Mineral Chemistry section was renamed as the Chemistry of Solid Materials section. Hagenmuller, who had become the most influential mandarin of his generation, succeeded Michel as president of the section. In 1976, a division of solid-state chemistry and metallurgy was created at the French Chemical Society. And, in 1978, Hagenmuller and Paul Caro joined the French Academy of Science as associate members. Concurrently, solid-state chemistry was entering master's degrees. Even though the curriculum was not standardized, the teaching of solid-state chemistry spread across the country; in each university where a laboratory of solid-state chemists was settled, solid-state chemistry was taught.

As the discipline was stabilized in national institutions, the French community had won international fame. While the French largely published in the specialized journals founded in the United States and England since the mid1960s, they still wrote their articles in French. ${ }^{67}$ They knew the quality of their syntheses would bring them readers. ${ }^{68}$ Hagenmuller was considered abroad as

67. In 1976, the laboratory of Bordeaux, which was one of the most international of the French community, published only ten percent of its articles in English.

68. "That the new compounds [in which new phenomena have been discovered in the past two decades] were with few exceptions synthesized originally in Europe is no surprise. Inorganic chemistry, especially solid-state chemistry, is strong in France and Germany." Franck Di Salvo, "New and Artificially Structured Electronic and Magnetic Materials," in Advancing Materials Research, ed. Peter A. Psaras and H. Dale Langford (Washington, DC: National Academy Press, 1987): I6I-76, on 164 . 
the best ambassador of the French community. In 1978, he carefully organized the first European Conference on Solid-State Chemistry in Strasbourg, with Jean-Claude Bernier. It would be held every three years afterwards. Solid-state chemistry, which around 1980 was institutionalized in France and internationally acknowledged, seemed to reach the stable status of an academic discipline. However, its stability was challenged by centrifugal forces that stirred the French academic system.

\section{THE CLUSTER REGIME OF MATERIALS, 1985-PRESENT}

\section{The Softening of Academic Structures}

Even during the 1970s, when the disciplinary matrix was highly standardized, the community retained two kinds of local heterogeneities: among laboratories and inside the laboratory. Indeed, even if the feudal regime was less crucial, laboratories remained influenced by their own history and still conducted distinctive research programs according to chemical elements (oxide, sulfide, alkaline, etc.), methodology (relative stress on synthesis, structure, property, or applications), or instrumentation (diffraction, thermal analysis, or spectroscopy). ${ }^{69}$ Inside a laboratory, scholars could be either a "crystallo-chemist," or "crystallographer," or "physical chemist," depending respectively on their know-how in synthesis, structural analysis, or physical characterizations. Until the late I970s these heterogeneities had little weight compared to the strong identity of solidiste.

Things changed when new trends pervaded the French academic system, rendering it more democratic, more applied, and more porous. First, the postI968 political fallout made hierarchy less acceptable locally and favored the decentralization of power. ${ }^{70}$ First postwar-generation professors, who still directed "their" laboratories, retired in the I980s after three decades of power. To prevent the same situation from occurring again, the 1982 Law of Orientation and Programming of Technological Research and Development forbade the

69. Collongues's and Pâris's group were specialists of oxides, Flahaut's of sulfides, Prigent's of fluorides, Hérold's of alkaline graphites, Trombe's of rare earths, and so on. Hagenmuller was the only one who sought to tackle all kinds of ionic crystals.

70. This trend began slightly before 1968-in 1966-when the CNRS executive branch decided that each CNRS laboratory would have an advisory committee (conseil de laboratoire) composed of outside and inside representatives to balance the power of directors. Prost, "Les réformes" (ref. 64). 
directorship of an academic laboratory for more than three mandates, or twelve years (règle des douze ans). Following the 1968 Orientation Law, the CNRS experienced major decentralization from the mid-I970s onwards, which gradually reduced the supremacy of Paris. ${ }^{71}$ In addition, a national committee of universities was created in 1986 to give the university system a unified mechanism for decision-making and counterbalance the CNRS's weight.

Second, when state-funding decreased in the early 1970s, a situation made worse by the oil crisis of 1973 and 1980 , scholars were more and more pushed toward private funding. After 198I, and the election of François Mitterrand (198I-1995) as president, the socialist government formalized the collaboration of academia and industry, and materials research became one of the priorities of French science policy. ${ }^{72}$

Third, a significant number of students went abroad for postdoctoral research, and the lateral mobility from one laboratory to another became easier. A new policy favored the establishment of large multidisciplinary institutes in the late 1980s. The first for solid-state chemistry was the Institute of Materials in Nantes, which brought together two heirs of Hagenmuller-Jean Rouxel and Michel Tournoux — and solid-state physicists. It was entirely new in France for physicists and chemists to be associated as equals in a given laboratory. The increasing mobility of scientists went hand in hand with the accessibility of information, which was enhanced from the I990s onward by the development of the World Wide Web. ${ }^{73}$

\section{A New Organization of Sciences by Research Aggregates}

In the 1980s, as the first postwar generation retired and the Comité national became less crucial for funding (industrial collaborations), prestige (international openness), and authority (multidisciplinary institutes and decentralization), the younger generations reacted strongly against the standards of the $1970 .^{74}$

7I. Clark, Places of Inquiry (ref. 47), 98 and III.

72. Between 1982 and 1994 , this ambition was carried out by a CNRS interdisciplinary program in materials research (PIRMAT) that associated chemists, crystallographers, physicists, and industrialists.

73. See, for example, Nathalie Pignard-Cheynel, La communication des sciences sur Internet: Stratégie et Pratiques (PhD dissertation, Université Stendhal Grenoble 3, 2004).

74. From the I970s onward, unlike previously, it became impossible to analyze the distribution of actors according to distinct generations, which justifies a broader category. 
Novel syntheses, objects of study, and instruments blossomed around the new label of "soft chemistry" (chimie douce). ${ }^{75}$ All elements of the disciplinary matrix were superseded. High-temperature synthesis was challenged by low-temperature techniques in solution to enlarge the range of available solids. Three-dimensional crystals lost hegemony when low-dimensional solids exhibited exotic properties. ${ }^{76}$ Porous solids, as well as surface and interface phenomena, reemerged because of their interest to the catalytic industry. ${ }^{77}$ Hybrid compounds made of organic molecular chains and mineral matrixes were extensively studied, as were composite materials. More techniques were needed to characterize the wider range of solids: electron microscopy, electronic paramagnetic resonance, nuclear magnetic resonance, and $\mathrm{x}$-ray diffusion (synchrotron). This instrumental shift was made possible by the availability of computer facilities in the I970s. Chemists became more interested in quantum mechanics after the 1980 s because they needed it to understand new techniques, model the solid state, and synthesize new compounds (by predicting their theoretical stability).

This renaissance of practices altered solid-state chemistry. Epistemic boundaries blurred: some chemists perceived solid-state chemistry to be every type of chemistry except molecular chemistry, while others, involved in "sol-gel process," worked on a continuum from molecules to solid compounds. ${ }^{78}$ As the disciplinary matrix widened, solid-state chemists started referring to larger umbrellas, at least three around 2000. First, they were dispersed among several trends of chemistry. ${ }^{79}$ Second, they started to include the solid state inside condensed matter, as

75. Some of these novelties had already been investigated beginning in the I960s, but they were marginal, at least in France, because they differed from the standardized disciplinary matrix. Chimie douce was first publicized by Jacques Livage, Le Monde, 26 Oct 1977.

76. At the crossroads of alkaline graphite (Hérold) and sulfide (Flahaut), Rouxel launched a fruitful topic around the low-dimensional (lamellar and thread) sulfides. In I997, he received the highest French scientific award — the CNRS Gold Medal—the second solid-state chemist after Chaudron in 1969.

77. See Baptiste Voillequin, Contribution à l'histoire de la catalyse en France (1944-2004): Dynamiques disciplinaires et régimes de production de savoir ( $\mathrm{PhD}$ dissertation, Université Paris Io Nanterre, 2008), esp. 94, 176, and 233-38.

78. Solid-state chemistry "is non-molecular chemistry, everything except chemistry of carbon, which might allow development toward high technology materials." Jean-Luc Adam, interview by author, 7 Feb 2006, Rennes. "Sol-gel" syntheses consist of molecular precursors that react and grow to form a gel in suspension and then a solid (sol) that precipitates. "We work on nanometric objects: we start from molecules and try to build solid compounds." Jean-Pierre Boilot, interview by Bernadette Bensaude-Vincent, I2 Dec 2000, Palaiseau.

79. At the I5oth anniversary of the French Chemistry Society in July 2007, solid-state chemists gave lectures in four of the six sessions: "Beyond the Supramolecular Chemistry" (Gérard Férey), "Chemistry and Materials" (Maryvonne Hervieu, Roger Naslain), "The Booming of Solid-State 
physicists had done three decades earlier. ${ }^{80}$ In 1995 , the emblematic laboratory of Hagenmuller was renamed the Institute of Condensed Matter Chemistry of Bordeaux; and, in 2002, when Livage was appointed professor at the Collège de France, he labeled his chair Chemistry of Condensed Matter. Finally, and more deeply, solid-state chemistry shifted toward materials science; first used as a buzzword for the CNRS section between 1975 and 1990, "materials" became a label for nearly half the laboratories of the community by $2000 .{ }^{81}$ (Fig. 5) "Nano-materials," "biomaterials," and "green materials" successively reached and reshaped solid-state chemistry. ${ }^{82}$ This gradually moved solid-state chemists closer to the processing of basic materials and away from the exploration of original solids. ${ }^{83}$

As the epistemic coherence diffused as a result of the multiplication of references, the community organization changed once again. The self-identification faded: significantly, younger generations no longer forged a collective discourse and knew little about the past. The rise of individualism and mobility brought the mandarin era (1945-1985) to an end. Laboratory life changed: individual initiative took precedence over central planning and competition over collaboration. ${ }^{84}$ The competition, which was mainly national during the previous era, was generalized at international, national, and local levels, and national borders

Chemistry" (Jacques Livage, Jean-Pierre Doumerc, Patrick Maestro, Jacques Lucas), and "Chemistry, Energy, and Ecology" (Jean-Marie Tarascon).

80. When Pierre Gilles de Gennes (1932-2007) was appointed professor at the Collège de France in 1971, he labeled his chair Physics of Condensed Matter. Later, in the 1970s, the CNRS section of Solid-State Physics became that of Condensed Matter Physics.

81. Chemistry of Solid Materials (1975-1982); Chemistry and Physical Chemistry of Inorganic Materials (1983-1987); and Physical Chemistry of Materials (1988-1990). Oddly, the word "materials" disappeared during the 1990 os, and the section became Elaboration, Characterization, and Modeling the Solid (I99I-2004).

82. The CNRS section was renamed Chemistry of Materials, Nanomaterials, and Process in 2004.

83. "There is in France the entire range of activities from pure solid-state chemistry to pure materials science." Michel Pouchard, interview by author, 20 Sept 2004, Paris. "Fortunately, or unfortunately according to one's viewpoint, solid-state chemistry quickly turned to the application of what was done in the laboratory because of the presence of a large industry of applications ... the exploratory side has suffered from this." Hervé Dexpert, interview by author, 8 Jun 2006, Toulouse.

84. "The mandarin system (mandarinat) created links among young generations [whereas now] people protest." Danielle Serreau (a laboratory secretary who started her career in the 1960 ), interview by author, I8 Nov 2004, Paris. "Now, young scholars between thirty and forty years old [younger generations] quickly want to have their subjects, their money, their contracts, their $\mathrm{PhD}$ students. ... They want to boost their careers, which makes them more pushy, more individualistic." Andrée Kahn-Harari, interview by author, 23 Feb 2004, Paris. 
were no longer as relevant as they had been. This entity, composed of atomized, flexible research teams in competition with each other and driven by political and economic forces outside themselves, could barely be considered a community: there was no consensus on practices, no self-identification, and multiple references. In short, the centralized, national republic was turned into a multicentered scientific market plunged into a pidgin-English world. ${ }^{85}$

How, then, were French solid-state chemists organized? While the community faded and blurred from the 1990s onwards, solid-state chemistry was perceived as a common viewpoint, a vague grouping united more by a common philosophy than by a consistent community. ${ }^{86}$ In everyday life, each solid-state chemist was involved in his or her specific topics for which he or she interacted with other communities: on intercalated solids with electrochemists and battery engineers, on porous solids with theoreticians and catalysts, on hybrids with opticians, polymer scientists, and organic chemists, etc. The sum of these researchers with different (disciplinary and national) identities who gathered for a while on a given topic formed what can be labeled a research aggregate.

A research aggregate is a multidisciplinary community of researchers who interact around the same object (high-temperature superconductors), instrument (electron microscopy), or methodology (soft chemistry). Informal at the beginning, it can soon be structured by scientific conferences and administrative programs but not by university courses. It can also be characterized by a denser node of communication within the research field. ${ }^{87}$ It is transient and flexible, which allows a recombination under changing conditions, as exemplified by the "fluoride glass" case (1972-1983)..$^{88}$ Though not new, the research

85. This switch of regime was part of an international trend extensively studied by scholars since the controversial, programmatic book by Michael Gibbons, Camille Limoges, Helga Nowotny, Simon Schwartzman, Peter Scott, and Martin Trow, The New Production of Knowledge: The Dynamics of Science and Research in Contemporary Society (London: Sage Publications, 1994).

86. To the question "Are you integrated into the community of solid-state chemistry in France?" a researcher who completed his $\mathrm{PhD}$ in the mid-I980s answered: "Yes, we are, but it is rather a community with a common viewpoint of what should be chemistry of solids. But our scientific interactions are not with this community." Adam, interview, 7 Feb 2006 (ref. 78).

87. Co-citation analysis would help to quantify the dynamics of the research aggregates involved and visualized their forms. See, for example, Matthew L. Wallace, Yves Gingras, and Russel Duhon, "A New Approach for Detecting Scientific Specialties from Raw Cocitation Networks," Journal of the American Society for Information and Technology 60, no. 2 (2009): 240-46.

88. Fluoride glasses were first synthesized in 1972 in Jacques Lucas's Laboratory of Solid-State Chemistry in Rennes. These materials appeared to have such good optical properties that within a few months around forty laboratories of engineering, optics, thermodynamics, chemistry, and telecom aggregated and for ten years formed a small, flexible research community. When it turned 
aggregate nonetheless became a more relevant category in the late twentieth century, when national and disciplinary references declined and funding buzzwords rose. Thus, as solid-state chemists were increasingly organized by a set of aggregates (i.e., a "cluster") from the I990s onwards, they experienced a cluster regime. This regime was defined by a more or less consensual idea of what solid-state chemistry should be, cohered by social habits inherited from the previous era, and permeated with the values and practices of materials science. In short, it was a cluster regime of materials.

\section{SOLID-STATE SCIENCE IN FRANCE: A MULTIDISCIPLINARY PERSPECTIVE}

This case study has shown the mutability of the French community of solidstate chemists since World War II. Framed by a university regime of research schools in the mid-twentieth century, the community was reshaped in the I960s according to CNRS standards to become a centralized, nationwide disciplinary republic of mandarins in the I970s united by a strong collective identity of solidiste. The culture of cumul made university professors cogwheels of integration throughout the system. ${ }^{89}$ When the era of mandarins came to an end, the disciplinary regime gradually faded while the circulation of objects, information, and people renewed solid-state chemistry and dispersed solid-state chemists across a cluster regime of materials. This flexible regime made of transient aggregates may become the common organization of sciences in the twenty-first century.

The traditional community, however, remains the right scale of analysis for the French academy in the second half of the twentieth century. If the threeregime narrative is too dependent on the peculiarity of solid-state chemists to be directly transposed, it holds many features worth comparing to other subdisciplines, in particular the alter ego of physics. In France, solid-state physics and chemistry were twin disciplines with equivalent sizes, academic settlement,

out that applications would be too expansive, the research aggregate joined other aggregates to launch the International Symposium on Non-Oxide Glass in 1983.

89. Institutional studies usually emphasized the partition rather than the integration of the French academy. See Guy Neave, "Séparation de Corps: The Training of Advanced Students and the Organization of Research in France," in The Research Foundations of Graduate Education: Germany, Britain, France, United States, Japan, ed. Burton R. Clark (Berkeley: University of California Press, 1993): 159-9I. 
and autonomy, and entrenched in the same universities/CNRS opposition and research schools system. ${ }^{90}$ There were nonetheless two important differences between physicists and chemists during that time. First, most mandarins of physics were normaliens educated in the same prestigious École Normale Supérieure, which increased their kinship through education. ${ }^{91}$ Second, unlike chemists, French physicists were deeply influenced by the United States, perceived as the El Dorado of physics after $1945 .{ }^{92}$ They quickly sent postdoctoral scholars abroad and adopted the American model of summer schools: starting in the summer of 1951, physicists gathered once a year in the Alpine village of Les Houches to discuss recent international research. Such habits came later for chemists, in the I970s. The first summer school of solid-state chemistry, Galerne (named after a wind from Brittany) was launched in 1977 by Rouxel.

This induced a radical divergence of physicists and chemists with respect to national organizations. As solid-state physics had already been established abroad since the 1930s, the French community endorsed international standards, in particular the three pillars of solid-state physics: x-ray crystallography, theory of bands, and structure-property relationship. ${ }^{93}$ As solid-state chemistry did not yet exist abroad, first postwar-generation chemists built a discipline according to their own national standards. Such an organizational imperative forced them to become "scientific-administrators" rather than "scientificentrepreneurs," as some of their physicist colleagues-Néel, Yves Rocard (19031992) — could afford to be. ${ }^{94}$ Without organizational imperative, solid-state physicists did not build a nationwide community and remained concentrated in a few areas: Paris, Grenoble, Toulouse, and Strasbourg.

Social divergences echoed epistemic ones. Chemists' disciplinary matrix was structured by the scientific objects from one era to another-continuous solid-state

90. The U.S. case, on the contrary, exemplifies a huge difference of weight: the 1973 American Men and Women of Science listed around seventy solid-state chemists and nineteen hundred solidstate physicists!

9I. This is a general difference between physics and chemistry: a survey of the current composition of the French Academy of Science shows that all physicists but two were educated at the École Normale Supérieure, whereas, for chemistry, normaliens are rather the exception than the rule.

92. Dominique Pestre, "Sciences physiques et recherche industrielle et militaire en France: un changement historique de régime," in Les sciences pour la guerre, 1940-1960, ed. Amy Dahan and Dominique Pestre (Paris: Éditions EHESS, 2004): 317-4I.

93. Weart, "Solid Community" (ref. 25), 623.

94. François Jacq and Dominique Pestre, "Une recomposition de la recherche académique et industrielle en France dans l'après-guerre, 1945-1970: Nouvelles pratiques, formes d'organisation et conceptions politiques," Sociologie du travail 3 (1996): 263-77. 
(1945-1960), ionic crystals (1960-1985), and materials (1985-present)—but also from one research school to another (the partitioning of the periodic table). This was entrenched in a realist conception of matter: French solid-state chemists were willing to handle real matter however badly characterized, uneasy to model, or useless for applications. They would never have called it "dirty matter," as some physicists did, because they were used to working at the bench, where matter was everything but clean. ${ }^{95}$ This empirical culture favored their synthetic expertise, especially in crystallo-chemistry. It did not mean, however, that they refused to tackle "pure" solids. ${ }^{96}$ The interest for real objects had been taught by prewar mandarins and was renewed by industrial collaborations and applied education-none of the influential French solid-state chemists was normalien but many were chemical engineers (Bénard, Michel, Collongues, and Pâris for the elders).

On the contrary, French physicists' disciplinary matrix was based on phenomena and not matter. They instead studied simpler, often binary, compounds, either metallic alloys or ionic crystals. As chemists did with chemical composition, physicists divvyed up the solid state according to physical properties: electronic in Orsay, semiconducting in Paris, magnetic in Grenoble and MeudonBellevue, atomic in Toulouse, optic in Lyon, etc. ${ }^{97}$ This focus on phenomena made physicists more interested in precise measurements than in the individuality of a piece of matter. ${ }^{98}$ The Laboratory of Solid-State Physics in Orsay, driven by outstanding normaliens, was paradigmatic of the mathematical culture of French

95. The reluctance of some physicists to deal with dirty matter was clearly expressed by Wolfgang Pauli in the early 1930s: "I consider it harmful when younger physicists become accustomed to order-of-magnitude physics. The residual resistance is a dirt effect and one shouldn't wallow in dirt." Cited in Lillian Hoddeson, Gordon Baym, and Michael Eckert, "The Development of the Quantum Mechanical Electron Theory of Metals, 1926-1933" in Out of the Crystal Maze (ref. I): 88-I8I, I8I, note 458.

96. A research program on pure metals was conducted in the I96os by Chaudron and Trombe, which led to the publication of Georges Chaudron, ed., Monographies sur les métaux de haute pureté, 3 vols. (Paris: Masson, 1972).

97. This division was clear in CNRS sections' names (1945-1966): Optics, Thermodynamics, Electricity/Magnetism, Molecular Physics, and Corpuscular Physics. Virginie Durand and Catherine Nicault, eds., Histoire documentaire du CNRS. Tome I (années 1930-1950) and Tome 2 (années 1950-198I) (Paris: CNRS éditions, 2005 and 2006).

98. "I think that physicists are more gregarious than chemists, I mean they don't mind all doing the same measurements on the same material in the same time. I attended conferences on organic metals where there were four hundred physicists and two hundred did the same measurement. . . . It does not exist in chemistry, we [chemists] are more jealous about our originality ... a solid for them, to some extent . . . is a chemical black box." Alexandre Moradpour, interview by author, 7 Jul 2006, Orsay. 
physicists. ${ }^{99}$ Quantum mechanics, especially the theory of bands, was at the heart of physicists' knowledge, even though it was not critical in chemistry until the r99os.

These entrenched disciplinary cultures made multidisciplinary collaborations difficult in France. Until the 1950s, most interactions took the form of mandarinto-mandarin discussions: Hagenmuller and Jacques Friedel for example, or Pâris and Néel. In the 196os, more second postwar-generation researchers collaborated with French physicists in need of single crystals. For physicists, single crystals were indispensable to run the international race of physical characterizations. ${ }^{100}$ Physicists usually thought that chemists' work consisted in growing, purifying, and shaping crystals. Although they might perform these activities, chemists depreciated them and considered them a duty for technicians. ${ }^{101}$ They were convinced that their true expertise lay in synthetic originality. French chemists grew frustrated when physicists refused the original solids they synthesized just because these new solids were not easy to model. The vanadium oxides $\left(\mathrm{V}_{2} \mathrm{O}_{5}\right)$, which were synthesized by chemists in the 1960s, did not interest French physicists at the time, though they became star model compounds of international physics in the 1990s. ${ }^{102}$ Chemists, however, usually agreed to synthesize and process for physicists because there was a return benefit: they could then rely on physicists' subtle characterizations. ${ }^{103}$ In the I970s and I980s, the cultural gap was partly filled when $\mathrm{PhD}$ students built bridges between the two communities. ${ }^{104}$

The strength of disciplinary boundaries had both advantages and drawbacks. Such boundaries allowed each community to keep its economic autonomy and to develop its own know-how: synthesis and simple characterizations for chemists

99. This laboratory was founded in 1959 at the University of Orsay by three famous normaliens: Raimond Castaing (192I-1998), Jacques Friedel (born in I92I), and André Guinier (I9II-2000).

Ioo. This trend was advanced by the U.S. telecom industry. For example, Néel and Félix Bertaut started growing iron garnet crystals in the late I950s because they competed with Matthias at Bell Labs who did it in I955. Pestre, "Louis Néel" (ref. 34), 97-IIO.

Ior. This situation was pointed out for the Laboratory of Solid-State Physics in Orsay, where chemists had to do what physicists ordered even if they considered it technical (anonymous interview).

IO2. Jean Galy, interview by author, 6 Jun 2006, Toulouse; and Denis Jérôme (heir of Friedel), interview by author, I6 Jun 2006, Orsay.

IO3. Hagenmuller gave this following advice to his students: "Do physics to speak with physicists and make crystals to work with them." Pouchard, interview, 20 Sep 2004 (ref. 83).

I04. In the I970s, a typical collaboration (on ionic superconductors) was conducted by a $\mathrm{PhD}$ candidate working in between ( $\dot{a}$ cheval) a laboratory of physics and a laboratory of chemistry. Later, in the I980s and I990s, there would be two PhD candidates-one of physics and one of chemistry-working together. 
versus subtle characterizations and models for physicists. However, the disciplinary gap often resulted in a lack of discussion, which prevented French solid-state chemists from fully characterizing their original compounds and demonstrating their amazing properties: Chevrel's phases, "cuprates," and beta-alumina were three missed occasions where a closer collaboration with physicists would have allowed French chemists to launch a hot topic on the international stage. ${ }^{105}$ Néel's research school in Grenoble was an exception, since physicists there esteemed chemists' syntheses. Félix Bertaut (1913-2003) in particular was envied by the community of solid-state chemists since he was an excellent chemist and crystallographer working in harmony with physicists in a laboratory of physics. However, when, in 1970, Néel was awarded the Nobel Prize in Physics for his work on antiferromagnetism and ferromagnetism, he did not stress the importance of chemical knowledge in his success. ${ }^{106}$

The question of disciplinary autonomy implies competition. Within a community, research schools implicitly reached a gentlemen's agreement to give each one a special area to study (a type of solids for chemists, a type of property for physicists). This reduced the epistemic competition, but economic competition remained brutal: more than two-thirds of laboratory funding came from the same public institutions (CNRS, universities), for which all research schools competed. In their own community, chemists were proud to say what they owed to physics because it was seen as a guarantee of modernity. But they also suffered from physicists' lack of consideration. ${ }^{107}$ When solid-state chemists competed with physicists for prestige, they always lost. They were not awarded a single Nobel Prize (in France or abroad) whereas solid-state physicists were crowned several times. ${ }^{108}$ Solid-state chemistry experienced the same low

I05. In the early I980s, Bernard Raveau (heir of Deschanvres) and his team in Caen published the synthesis, crystalline structure, and unexpected electric conductivity at room temperature of new cuprates. A few years later, in April 1986, Karl Müller and Johannes Bednorz from IBM in Zurich revealed the superconducting properties of similar phases up to $30 \mathrm{~K}$, which led them to the Nobel Prize in Physics in 1987. This case was commonly recalled as the missed Nobel Prize of French solid-state chemists.

IO6. Néel's theoretical work deeply relied on original solids, in particular the iron garnets that were first synthesized by Bertaut with the help of Hubert Forestier (heir of Chaudron) and Trombe as explained by Pestre, "Louis Néel" (ref. 34), 97-IOI. Yet, Néel barely mentioned his chemist colleagues in his autobiography: Un siècle de physique (Paris: Odile Jacob, 1991).

I07. History of physics also tends to underestimate chemists' role for physicists. For example, chemistry and solid-state chemistry are not included in the index of Out of the Crystal Maze (ref. I).

I08. Strictly speaking, Néel's Nobel Prize was the only one to explicitly mention the reference to solid-state physics in the awards. However, several others in the second part of the twentieth century were closely related to this sub-discipline: Shockley, Bardeen, Brattain (1956), Mott and van Vleck (1977), and those linked to superconductivity (1972, 1973, 1987, and 2003). 
esteem with regard to solid-state physics as solid-state physics did with regard to high-energy physics.

This disciplinary comparison proffers three lessons at epistemic, social, and identity levels. First, chemists were more interested in the making of real matter - the original dirty piece of matter-whereas physicists focused on measuring and modeling subtle phenomena. Second, the degrees of making, realism, dirt, and individuality were inversely proportional to those of prestige. Third, the lack of prestige and public recognition was counterbalanced by the self-identification with a heroic cooperative community.

Although most actors involved may think the previous narrative is a simplification of what happened to them, I sought to stress the complexity of a community life. The analysis of the three regimes-research schools, disciplinary community, and research cluster-emphasized the evolving relations among the scientific objects, the institutional organization, and the perceptions of the actors. The same expression, "solid-state chemistry," reflected different realities from one era to another, but also from one place to another at a given time. It seemed invisible to a layman, homogeneous to a physicist, and finely divided to a chemist. For the historian, it was inescapably marked by the changing discourses of actors about their own history. In spite of their ambiguity, these words partly told what solid-state chemistry was: a dynamic group of chemists who forged new objects of study — the mutable solid state—and renewed their identities by modifying their practices and rewriting their past.

\section{ACKNOWLEDGMENTS}

This article would have not been possible without the support of the French Ministry of Education, the Maison Française d'Oxford, and the Chemical Heritage Foundation. I am grateful to Bernadette Bensaude-Vincent for her guidance during my research. I appreciate many valuable comments from Hervé Arribart, Hiro Hirai, Ernst Homburg, David Kaiser, Roy McLeod, Gigi Naglak, and Terry Shinn. The critiques of the referees, John Krige and Cyrus Mody, and the editorial board of Historical Studies in the Natural Sciences, helped me to clarify my words. Finally, I am glad to offer gratitude to my informants, especially French solid-state chemists. 